\title{
Role of the angiotensin II system in regulation of ovulation and blood flow in the rat ovary
}

\author{
K. Mitsube ${ }^{1,2 *}$, M. Mikuni ${ }^{2}$, M. Matousek ${ }^{1}$, U. Zackrisson ${ }^{1}$ and M. Brännström ${ }^{1}$ \\ ${ }^{1}$ Department of Obstetrics and Gynecology, The Sahlgrenska Academy at Göteborg University, \\ Göteborg, Sweden; and ${ }^{2}$ Department of Obstetrics and Gynecology, Hokkaido University \\ School of Medicine, Sapporo, Japan
}

The aim of the present study was to examine the roles of the angiotensin II receptor subtypes, $\mathrm{AT}_{1}$ and $\mathrm{AT}_{2}$, in ovulation, and to evaluate the contribution of angiotensin II-mediated pathways in regulation of ovarian blood flow. The $\mathrm{AT}_{1}$-specific antagonist, losartan, was administered alone or in combination with the $\mathrm{AT}_{2}$ specific antagonist, PD123319, to preovulatory rat ovaries perfused in vitro. Losartan $\left(100 \mu \mathrm{mol} \mathrm{I} \mathrm{I}^{-1}\right)$ did not affect the number of ovulations, whereas the combination of losartan $\left(100 \mu \mathrm{mol} \mathrm{I}^{-1}\right)$ and PD123319 $\left(10 \mu \mathrm{mol} \mathrm{I}^{-1}\right)$ inhibited ovulation. The angiotensin II antagonists did not affect the ovarian production of oestradiol, progesterone, prostaglandin $\mathrm{E}_{2}\left(\mathrm{PGE}_{2}\right), \mathrm{PGF}_{2 \alpha}$ or plasminogen activator activity. Ovarian nitric oxide production was inhibited by losartan. Ovarian blood flow was measured by laser Doppler flowmetry in vivo in preovulatory rat ovaries. Intrabursal injection of angiotensin II reduced ovarian blood flow of gonadotrophin-stimulated rats. Losartan had no effect on basal ovarian blood flow but completely blocked the angiotensin II-induced reduction. In contrast, treatment with PD123319 increased basal ovarian blood flow and failed to reverse the effect of exogenously administered angiotensin II, indicating that under physiological conditions, ovarian blood flow of the rat is negatively regulated by angiotensin II mainly through the action of $\mathrm{AT}_{2}$. Taken together, these results indicate that two different types of angiotensin II receptor facilitate ovulation by cooperative mechanisms and that they regulate ovarian blood flow in a different manner.

\section{Introduction}

The renin-angiotensin system has been recognized as an important regulator in mammalian homeostasis, mainly concerning the maintenance of blood pressure and electrolyte balance. Recent studies have shown that the renin-angiotensin system is localized in many extrarenal organs, such as the brain and the heart, with a broad spectrum of paracrine and autocrine functions (Kramar et al., 1997; Chin et al., 1998). All main components of the renin-angiotensin system are present in the ovary (Sealey et al., 1985; Lightman et al., 1987; Speth and Husain, 1988) and there is evidence that the ovarian renin-angiotensin system is involved in mammalian reproduction. The renin-angiotensin system in the ovary is upregulated by gonadotrophins (Fernandez et al., 1985; Sealey et al., 1985; Howard et al., 1988). The concentration of angiotensin II in human follicular fluid increases after treatment with hCG or LH (Lightman et al., 1987) and this result was confirmed by an

*Correspondence: Department of Obstetrics and Gynecology, Hokkaido University School of Medicine, N-15, W-7, Kita-ku, Sapporo, 060-8638, Japan

Email: ken_mitsube@hotmail.com in vitro study with rabbit ovarian perfusion (Yoshimura et al., 1994). It has been reported that angiotensin II induces rabbit ovulation (Yoshimura et al., 1996) and that the ovulation rate is decreased by the treatment with angiotensin II antagonists as demonstrated both in vivo (Pellicer et al., 1988) and in vitro (Peterson et al., 1993).

Angiotensin II exerts its actions through the binding to a group of receptors, which are subclassified into the angiotensin II receptor type $1\left(\mathrm{AT}_{1}\right)$ and angiotensin II receptor type $2\left(\mathrm{AT}_{2}\right)$. Most of the well-characterized functions of angiotensin II, such as vasoconstriction and the maintenance of electrolyte balance, are ascribed to the $\mathrm{AT}_{1}$ receptor, whereas physiological roles of the $\mathrm{AT}_{2}$ receptor are still uncertain. Both of these angiotensin II receptors are expressed in the ovary, and the presence and distribution patterns of the two receptors differ significantly among species and developmental stages of the follicle (Pucell et al., 1991; Obermüller et al., 1998). It was previously reported that the blockade of the $\mathrm{AT}_{2}$ receptor in the rat ovary by a specific $A T_{2}$ antagonist PD123319 did not inhibit ovulation, whereas a non-selective angiotensin II receptor antagonist saralasin reduced ovulation rate in the in vitro perfused ovary (Mikuni et al., 1998). These results indicate the 
importance in ovulation of the pathways mediated exclusively through $\mathrm{AT}_{1}$ or a combination of $\mathrm{AT}_{1}$ and $\mathrm{AT}_{2}$ in the rat ovary.

Angiotensin II is a potent vasoactive substance and part of its functions in the ovary may be related to the modulation of ovarian blood flow. During the growth of the ovarian follicle, the capillaries surrounding the antrum proliferate (Murakami et al., 1988), and ovarian blood flow further increases shortly after the preovulatory LH surge (Janson, 1975; Brännström et al., 1998) with a marked dilatation of the vessels around the ovulating follicles (Kranzfelder et al., 1992). Since sufficient blood supply to the ovary is necessary throughout the ovulatory process and ovarian steroidogenesis (Zackrisson et al., 2000), it is possible that angiotensin II affects ovarian vasculature and thereby ovarian function. However, the roles of angiotensin II and angiotensin II receptors on the regulation of ovarian blood flow have not been reported.

The aim of the present study was to explore further the functions of the angiotensin II receptors in the rat ovary during ovulation. The effects of an $\mathrm{AT}_{1}$-selective antagonist, losartan, alone or in combination with PD123319, on the ovulation rate and the ovarian production of ovulation-associated mediators were studied in the rat ovaries perfused in vitro. The effects of angiotensin II and angiotensin II antagonists on ovarian blood flow were studied in vivo by laser Doppler flowmetry allowing realtime measurement of tissue blood perfusion.

\section{Materials and Methods}

\section{Animals}

Immature female Sprague-Dawley rats (B\&K Universal, Sollentuna) were kept under a $14 \mathrm{~h}$ light:10 h dark cycle and had free access to pelleted food and water. All experiments were carried out according to the principles and procedures outlined in the NIH Guide for the Care and Use of Laboratory Animals, and were approved by the Animal Ethics Committee of Göteborg University.

\section{Hormones and chemicals}

Ovine luteinizing hormone (NIDDK-oLH-26) was kindly provided by the National Institute of Arthritis, Diabetes, Digestive and Kidney Diseases (NIADDK) and National Hormone and Pituitary Program (Rockville, MD). Human CG was purchased from Serono (Rome). Equine chorionic gonadotrophin (eCG), 3isobutyl-1-methylxanthine (IBMX) and angiotensin II were purchased from Sigma Chemical Company (St Louis, MO); ketamine was from Parke Davis (Barcelona); xylazine was from Bayer (Leverkusen); medium 199 was from GIBCO BRL (Rockville, MD); gentamicin sulphate was from Biological Industries (Kibbutz Beit Haemek); bovine serum albumin (fraction $\mathrm{V}$ ) was from Boehringer
Mannheim (Mannheim); insulin was from Novo Nordisk (Bagsvaerd) and heparin was purchased from Lövens (Ballerup). The angiotensin II receptor subtype-selective nonpeptide antagonists losartan (selective for $\mathrm{AT}_{1}$ ) and PD123319 (selective for $\mathrm{AT}_{2}$ ) were kindly donated by DuPont (Wilmington, DE) and Parke-Davis (Ann Arbor, $\mathrm{MI})$, respectively.

For the perfusion experiments, LH, losartan and PD123319 were dissolved in the perfusion media and stored at $-70^{\circ} \mathrm{C}$ until used. IBMX was dissolved just before use in perfusion media. For the laser Doppler experiments, stock solutions of hCG, angiotensin II, losartan and PD123319 were prepared with $0.9 \% \mathrm{NaCl}$ and kept at $-70^{\circ} \mathrm{C}$.

\section{Ovarian perfusion}

At 28 days of age, the rats were given 20 iu eCG s.c. to promote growth and maturation of a first generation of follicles to reach a large antral stage $48 \mathrm{~h}$ later. On the morning of day 30 of age, the rats were anaesthetized with $40 \mathrm{mg}$ ketamine $\mathrm{kg}^{-1}$ and $6.5 \mathrm{mg}$ xylazine $\mathrm{kg}^{-1}$, and 300 iu heparin sulphate was injected i.v. through the femoral vein. Laparotomy was performed and the right ovary was surgically removed with its feeding and draining vessels as described in detail by Brännström et al. (1987). The bursa was gently opened and the ovary was placed in a perfusion chamber. The perfusion was performed in a recirculating system with $30 \mathrm{ml}$ of medium (Medium 199 with Earl's salts supplemented with $0.026 \mathrm{~mol}$ sodium bicarbonate $\mathrm{I}^{-1}, 0.2$ iu insulin $\mathrm{ml}^{-1}, 50 \mu \mathrm{g}$ gentamycin sulphate $\mathrm{ml}^{-1}$ and $4 \%(\mathrm{w} / \mathrm{v})$ BSA). The perfusion pressure was maintained at $80 \mathrm{mmHg}$ and the medium was continuously gassed with $5 \% \mathrm{CO}_{2}$ and $95 \% \mathrm{O}_{2}$. The ovaries were perfused for 30 60 min before addition of any compound.

Losartan $(100 \mu \mathrm{mol} \mathrm{I}-1, n=11)$ alone or losartan $\left(10 \mu \mathrm{mol} \mathrm{I}^{-1}, n=6\right.$ and $\left.100 \mu \mathrm{mol} \mathrm{I}-1, n=5\right)$ in combination with $10 \mu \mathrm{mol}$ PD123319 I-1 was added to the perfusion medium 30 min before the administration of LH and IBMX. IBMX is a non-selective phosphodiesterase inhibitor, which was added to potentiate the LH effects to stimulate optimally the ovulation process in vitro (Peterson et al., 1993). Control ovaries were perfused at the same time as the treated ovaries but angiotensin II receptor antagonists were not present $(n=7$ controls for losartan alone and $n=13$ controls for PD123319 + losartan). The perfusion was continued for $20 \mathrm{~h}$ after administration of $\mathrm{LH}+\mathrm{IBMX}$. Samples of medium $(1 \mathrm{ml})$ were taken at $0,1,3,5,7,10$ and $20 \mathrm{~h}$ and stored at $-70^{\circ} \mathrm{C}$ for later analysis. At the end of the perfusion, the number of ovulations were determined by counting the ovulated oocytes present in the perfusion chamber under a stereomicroscope.

Another set of experiments with ovarian perfusion was conducted to measure the intra-ovarian content of the proposed ovulatory mediators, prostaglandin $E_{2}$ 
$\left(\mathrm{PGE}_{2}\right), \mathrm{PGF}_{2 \alpha}$ and plasminogen activator (PA) activity. The ovaries were perfused as described above for $10 \mathrm{~h}$ after LH + IBMX administration $\left(100 \mu \mathrm{mol}\right.$ losartan $\mathrm{I}^{-1}$, $n=5 ; 100 \mu \mathrm{mol}$ losartan $\mathrm{I}^{-1}+10 \mu \mathrm{mol}$ PD123319 $\mathrm{I}^{-1}$, $n=6$; control, $n=5$ ). At the end of the perfusion, the ovaries were removed from the perfusion chamber, snap frozen in liquid nitrogen and stored at $-70^{\circ} \mathrm{C}$ for later analysis (see below).

\section{Assays}

Oestradiol and progesterone concentrations in the perfusion media were analysed by radioimmunoassays. Nitric oxide (NO) produced by the ovary was analysed as total amount of nitrite $\left(\mathrm{NO}_{2}^{-}\right)$and nitrate $\left(\mathrm{NO}_{3}^{-}\right)$in the perfusion media. Ten microlitres each of nitrate reductase and cofactors (Alexis Corporation, Leufelfingen) was added to $100 \mu \mathrm{l}$ of sample to convert nitrate to nitrite. Greiss reagent (consists of $100 \mu \mathrm{l}$ $5.8 \mathrm{mmol}$ sulphanilic acid $\mathrm{I}^{-1}$ in $5 \%(\mathrm{v} / \mathrm{v}) \mathrm{H}_{3} \mathrm{PO}_{4}$ and $10 \mu \mathrm{l} 3.85 \mathrm{mmol} \mathrm{N}$-1-naphthylethylenediamine dihydrochloride $\mathrm{I}^{-1}$ in water) was added to each sample. After $60 \mathrm{~min}$ incubation at room temperature, the absorbance was measured at $550 \mathrm{~nm}$. Intra-ovarian $\mathrm{PGE}_{2}$ and $\mathrm{PGF}_{2 \alpha}$ concentrations were analysed by enzyme immunoassay assay kits (RPN 222 and TRK 900, respectively; Amersham Pharmacia Biotech, Little Chalfont). PA assay was performed according to the method by Espey et al. (1985) with minor modifications. Briefly, ovarian tissues were homogenized in ice-cold 0.05 mol Tris-HAc buffer $\mathrm{I}^{-1}$, sonicated and centrifuged $\left(10000 \mathrm{~g}, 20 \mathrm{~min}\right.$ at $\left.4{ }^{\circ} \mathrm{C}\right)$. Supernatant or standard solution, $20 \mu \mathrm{l}$, was mixed with $100 \mu \mathrm{l}$ of substrate S-2251 and $20 \mu \mathrm{l}$ of plasminogen (Chromogenix $A B$, Mölndal), and after $2 \mathrm{~h}$ incubation the absorbance was measured by UV-max ${ }^{\circledR}$ (Molecular Devices, Menlo Park, CA) at $405 \mathrm{~nm}$. Protein concentrations in the supernatant were measured by the BCA assay kit (Pierce, Rockford, IL). Inter- and intra-assay coefficients of variation were $<10 \%$ for all the assays in this study.

\section{Measurement of ovarian blood flow}

Laser Doppler flowmetry. At 26 days of age, all rats were treated with 15 iu eCG s.c. to promote the growth and maturation of a first generation of preovulatory follicles. Some animals were given hCG (15 iu, i.p.) 48 $\mathrm{h}$ later to induce the ovulatory cascade with predicted ovulation 12-15 h later.

Longitudinal measurement of ovarian blood flow was performed by laser Doppler flowmetry (Zackrisson et al., 2000). Ovarian blood flow was measured $46-48 \mathrm{~h}$ after eCG administration, when the ovary had reached a preovulatory stage, or 6-8 $\mathrm{h}$ after hCG, which is a time approximately half-way through the ovulatory stage. This stage corresponds to a time when ovarian blood flow is maximal after hCG stimulation (Abisogun et al., 1988; Makinoda et al., 1988).

The rats were anaesthetized with s.c. injection of $50 \mathrm{mg}$ ketamine $\mathrm{kg}^{-1}$ and $10 \mathrm{mg}$ xylazine $\mathrm{kg}^{-1}$ and placed on a heating pad to maintain body temperature at $37^{\circ} \mathrm{C}$. Tracheal intubation was performed to maintain patent airways and the iliac artery and the femoral vein on the left side were cannulated with PE-20 polyethylene catheters. Arterial blood pressure was measured from the iliac artery using a Grass polygraph (Grass Instruments, Quincy, MA). The animals were continuously infused with $0.5 \mathrm{mg}$ ketamine $\mathrm{kg}^{-1} \mathrm{~min}^{-1}$ and $0.1 \mathrm{mg}$ xylazine $\mathrm{kg}^{-1} \min ^{-1}$ in $0.9 \%(\mathrm{w} / \mathrm{v}) \mathrm{NaCl}$ through the arterial cannula during the experiment.

One ovary was exposed by a flank incision and stabilized by a ligature tied to the periovarian adipose tissue. The laser Doppler probe (Probe 407, Perimed $A B$, Stockholm) with an adhesive miniholder was placed on the ovarian surface, avoiding larger blood vessels, for the measurement of relative changes in ovarian blood flow. The probe and the incision wound were covered by an aluminum foil shield to minimize the effect of external light. The signal was analysed by a laser Doppler flowmeter (PeriFlux System 5000 with PF5010 laser Doppler perfusion monitor units, Perimed $\mathrm{AB}$ ) and was continuously recorded by PeriSoft software for Windows (Perimed $A B$ ). The ovarian blood flow was quantified as an arbitrary perfusion unit, which is proportional to the number and velocity of moving blood cells in an approximate tissue volume of $1 \mathrm{~mm}^{3}$ (Lissbrant et al., 1997). As the ovarian blood flow measured in different preparations could not be compared directly, the average flow between -5 and 0 min in relation to the initial injection time point was used as a basal level and the relative ovarian blood flow values were used for analysis. All experimental procedures were completed within 90 min after the laparotomy.

Experimental protocols. Ovarian blood flow was measured in rats either in preovulatory or ovulatory stage. The systemic effect was minimized by administering angiotensin II and angiotensin II antagonists locally into the ovarian bursa (intrabursally; i.b.). A polytetrafluoroethylene (PTFE) tube (diameter $0.4 \mathrm{~mm}$, ColeParmer International, Vernon Hills, IL), with the tip cut sharp, was attached to a micro-syringe filled with one of the following: $100 \mathrm{ng}$ angiotensin II, $40 \mu \mathrm{g}$ losartan, $40 \mu \mathrm{g}$ PD123319 (each in $5 \mu \mathrm{l} 0.9 \% \mathrm{NaCl}$ ) or the same volume of $0.9 \% \mathrm{NaCl}$, and was threaded through the periovarian adipose tissue into the ovarian bursa. Two of these preparations, one for the first injection and the other for the second injection, were made in each ovary according to the protocol below (Fig. 1).

After a stable blood flow signal had been recorded for at least $10 \mathrm{~min}$, one of the following: angiotensin II, losartan, PD123319 or $0.9 \% \mathrm{NaCl}$ as control was 


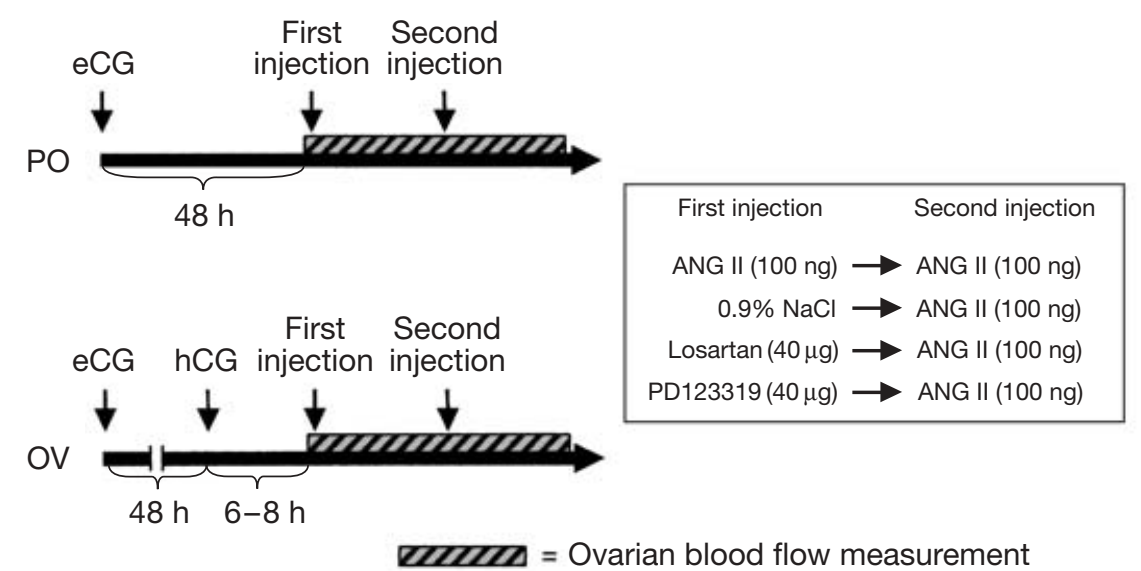

Fig. 1. The experimental protocols used in the rat ovarian blood flow measurement study. PO: preovulatory stage; OV: ovulatory stage; eCG: equine chorionic gonadotrophin; ANG: angiotensin.

injected into the ovarian bursa (first injection). Ten to fifteen minutes after the first injection, angiotensin II (100 ng in $5 \mu \mathrm{l} 0.9 \% \mathrm{NaCl}$ ) was administered intrabursally to all ovaries studied (second injection). The average blood flow between -5 and 0 min in relation to the first injection was used as a basal value and the relative value after each treatment was calculated. All the experimental procedures were completed within $90 \mathrm{~min}$ after the laparotomy. Between 30 and $50 \mu$ l of solution or air was injected through the tube at the end of each experiment to ensure that the expected bulging of the capsule wall took place, to confirm that the tube had actually been inserted into the bursal cavity.

\section{Statistical analysis}

Non-parametric tests were used in data analysis of the perfusion study, since in some of the experiments the data were not normally distributed. The results of intraovarian contents of $\mathrm{PGE}_{2}, \mathrm{PGF}_{2 \alpha}$ and PA activity were analysed by Mann-Whitney $U$ test. Number of ovulations and concentrations of steroids and nitrite or nitrate in the medium at each sample point were evaluated by KruskalWallis rank test followed by Mann-Whitney $U$ test. The results of the laser Doppler experiment were analysed using repeated measures ANOVA followed by Scheffe's test for the comparison within a group. Differences among multiple groups in response to the treatment were evaluated by one-factor ANOVA followed by Scheffe's test. $P<0.05$ was considered to be statistically significant.

\section{Results}

Effects on ovulation and ovarian mediators

The numbers of ovulations observed in the different treatment groups are summarized (Fig. 2). In the con- trol group $(n=7)$, there were 12.0 (median, 25-75\% range $=9.0-16.0$ ) ovulations per ovary. No significant difference was seen in the number of ovulations between the control and the group treated with $100 \mu \mathrm{mol}$ losartan $\mathrm{I}^{-1}$ (median $=8.0,25-75 \%$ range $=5.25-26.75, n=$ 11). The administration of losartan in combination with $10 \mu \mathrm{mol}$ PD123319 $\mathrm{I}^{-1}$ did not affect ovulation rate when $10 \mu \mathrm{mol}$ losartan $\mathrm{I}^{-1}$ was administered (median $=$ $12.5,25-75 \%$ range $=5.0-20.0, n=6$ versus median $=$ $12.0,25-75 \%$ range $=9.0-16.0$ for control, $n=11$ ), whereas when $100 \mu \mathrm{mol}$ losartan $\mathrm{I}^{-1}$ was administered it reduced the number of ovulations (median $=3.0,25$ $75 \%$ range $=1.75-4.5, n=5$ ).

In all groups, there were marked increases in secreted progesterone and oestradiol concentrations in the perfusion media after the administration of $\mathrm{LH}+$ IBMX. None of the angiotensin II inhibitors, given alone or in combination, significantly altered the gonadotrophininduced steroid concentrations (data not shown). The values of ovarian $\mathrm{NO}$ production, measured as total concentrations of nitrite and nitrate in the perfusate at 0,10 and $20 \mathrm{~h}$ sampling points (Fig. 3) show that in all treated groups, $\mathrm{NO}$ concentrations in the media increased with time after the gonadotrophin stimulation. At the $20 \mathrm{~h}$ time point, nitrite or nitrate concentrations were significantly lower in the group with $100 \mu \mathrm{mol}$ losartan $\mathrm{I}^{-1}$ compared with the control and the group with $100 \mu \mathrm{mol}$ losartan $\mathrm{I}^{-1}+10 \mu \mathrm{mol}$ PD123319 $\left.\right|^{-1}$.

No significant difference was observed among the tissue concentrations of $\mathrm{PGE}_{2}$ and $\mathrm{PGF}_{2 \alpha}$ in ovaries perfused for $10 \mathrm{~h}$ of the treated groups (Fig. 4a and b, respectively), although the median values were the lowest for both prostaglandins in the group with $100 \mu \mathrm{mol}$ losartan $\mathrm{I}^{-1}+10 \mu \mathrm{mol}$ PD123319 $\mathrm{I}^{-1}$. The administration of angiotensin II inhibitors did not affect PA activity in the ovarian tissue $10 \mathrm{~h}$ after the $\mathrm{LH}+\mathrm{IBMX}$ stimulation (Fig. 5). 


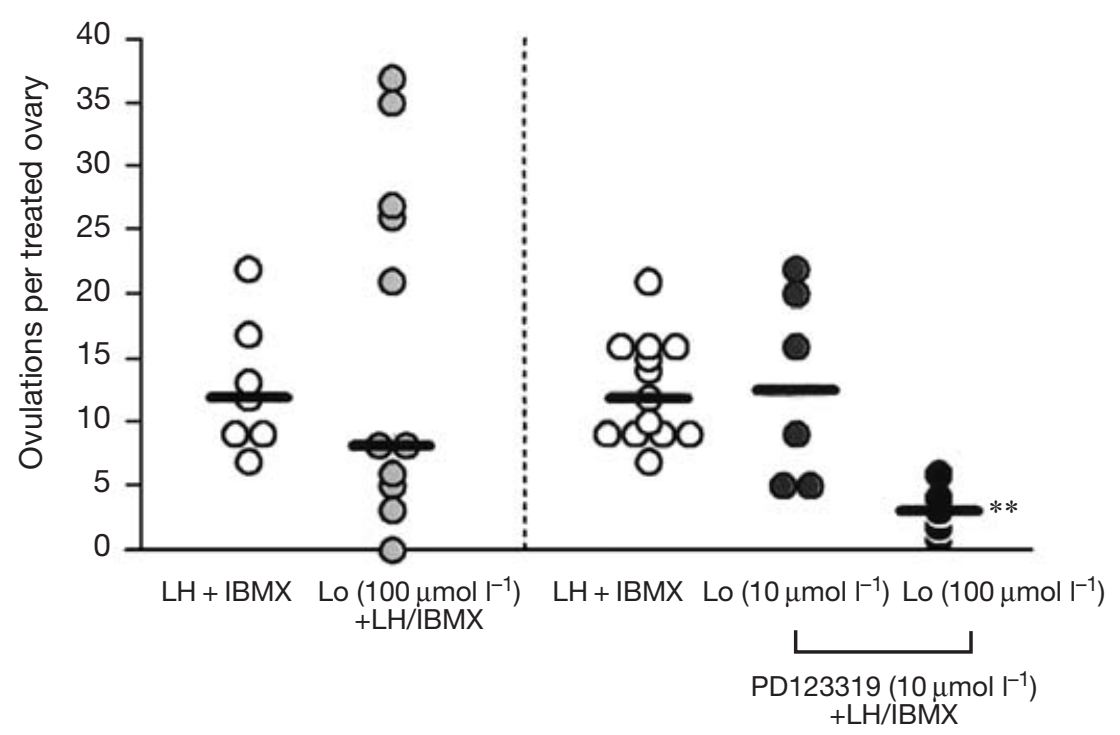

Fig. 2. Number of ovulations by rat ovaries after $20 \mathrm{~h}$ perfusions with angiotensin II receptor antagonists. The treatment with $100 \mu \mathrm{mol}$ losartan (Lo) $\mathrm{I}^{-1}$ alone $(n=11)$ did not affect the number of ovulations compared with that of the control group $(n=7)$. The combined treatment with $100 \mu \mathrm{mol}$ losartan $\mathrm{I}^{-1}+10 \mu \mathrm{mol}$ PD123319 I ${ }^{-1}(n=5)$ significantly $\left({ }^{* *} P<0.01\right)$ reduced the number of ovulations, whereas $10 \mu \mathrm{mol}$ losartan $\mathrm{I}^{-1}+10 \mu \mathrm{mol}$ PD123319 $\mathrm{I}^{-1}(n=6)$ did not affect the number of ovulations compared with the controls $(n=13)$. Individual values are shown and medians are indicated by horizontal bars. IBMX: 3-isobutyl-1-methylxanthine.

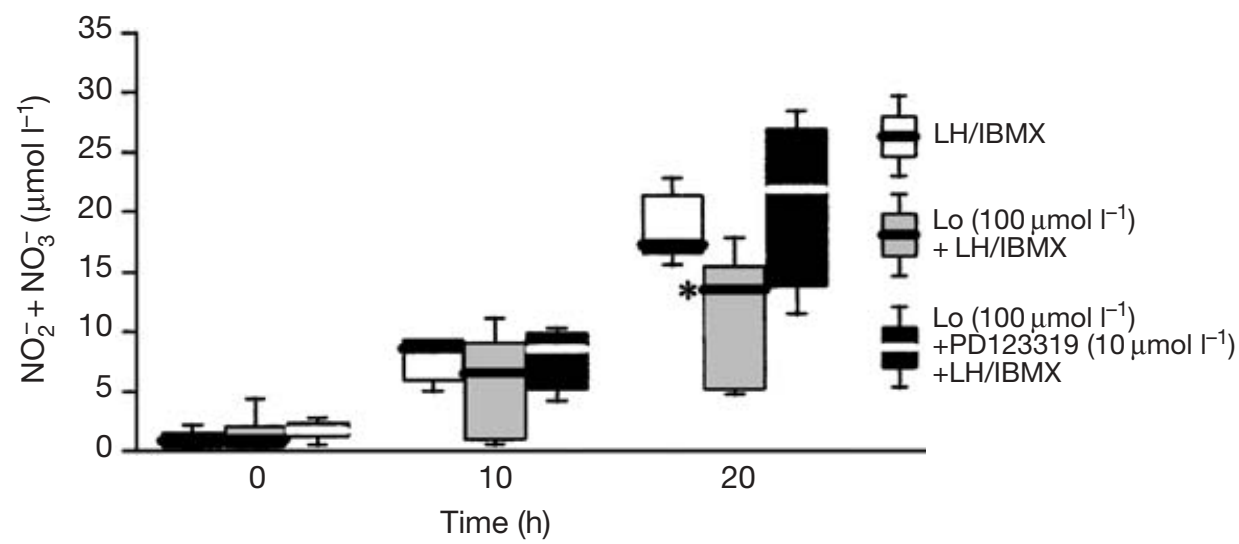

Fig. 3. Concentrations of nitrite + nitrate in the perfusion media used in the present study of rat ovaries. Administration of losartan (Lo) $(n=11)$ resulted in significantly lower concentrations of nitrite + nitrate at $20 \mathrm{~h}\left({ }^{*} P<0.05\right)$ compared with the controls $(\mathrm{LH}+\mathrm{IBMX} ; n=13)$. Treatment with PD123319 together with losartan $(n=5)$ abolished this decline in nitrite or nitrate production by the rat ovary. Bars indicate $10-90 \%$ range; boxes indicate $25-75 \%$ range and horizontal bars indicate medians. IBMX: 3-isobutyl-1-methylxanthine.

\section{Effects on ovarian blood flow}

Preovulatory stage rats. In our preliminary experiment, intravenous administration of $100 \mathrm{ng}$ angiotensin II to preovulatory stage rats caused a rapid and significant increase in mean arterial pressure and a reduction of ovarian blood flow that lasted for 5-10 min (data not shown). It is well established that ovarian blood flow is affected by changes in the systemic blood pressure (Wiltbank et al., 1990), and we could not exclude the possibility that systemic actions of angiotensin II might modulate ovarian circulation. Therefore, we used intrabursal administration of angiotensin II and angiotensin II antagonists for further experiments to 
(a)
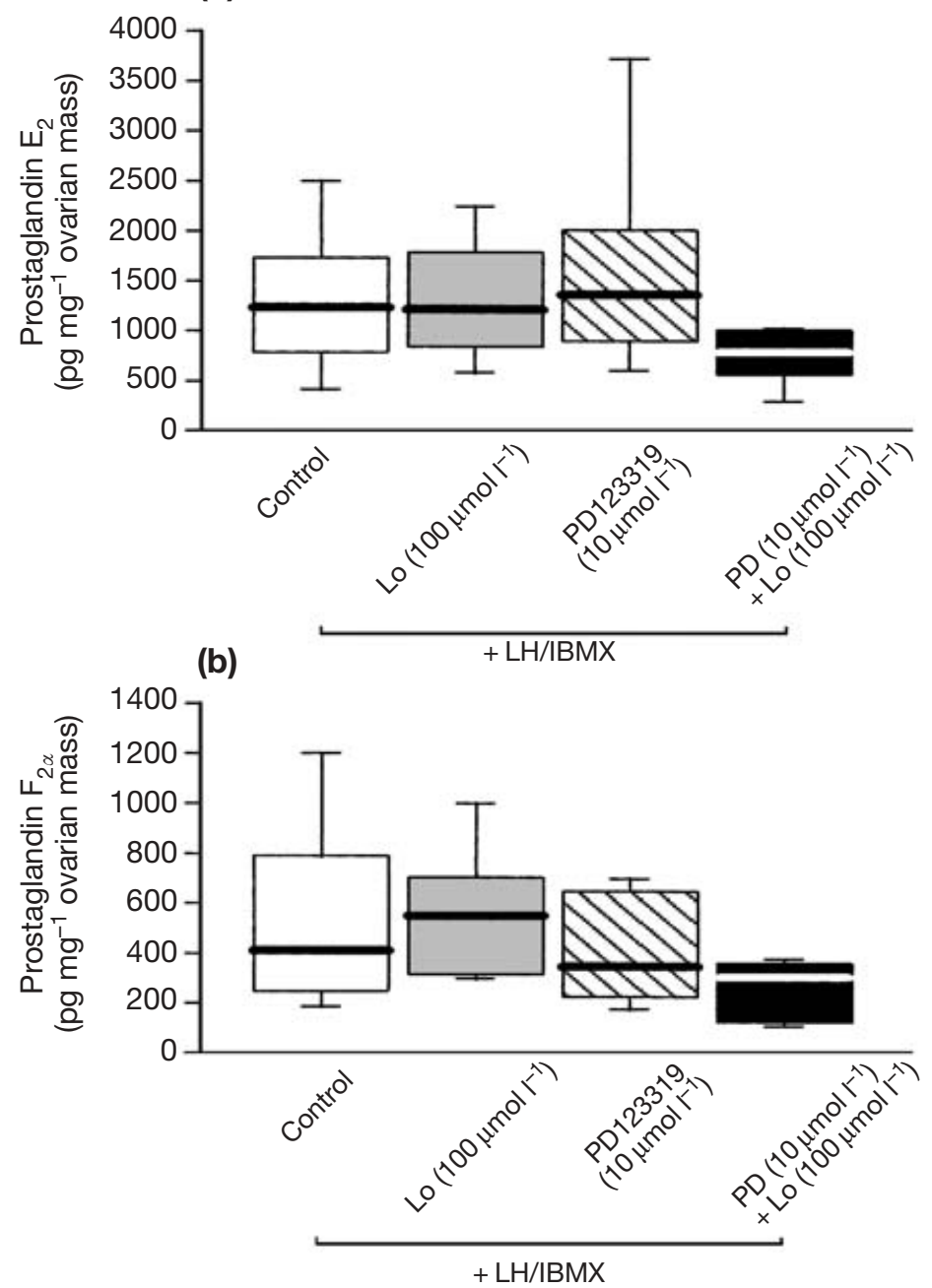

Fig. 4. (a) Prostaglandin $E_{2}\left(P E_{2}\right)$ contents of rat ovaries perfused for 10 h. Ovarian contents of $\mathrm{PGE}_{2}$ in ovaries perfused with $100 \mu \mathrm{mol}$ losartan (Lo) $\mathrm{I}^{-1}$ alone $(n=5)$ or $100 \mu \mathrm{mol}$ losartan $\mathrm{I}^{-1}+10 \mu \mathrm{mol}$ PD123319 $\mathrm{I}^{-1}$ $(n=6)$ were not significantly different from those of controls $(n=5)$. Bars indicate $10-90 \%$ range; boxes indicate $25-75 \%$ range and horizontal bars indicate medians. (b) Prostaglandin $\mathrm{F}_{2 \alpha}\left(\mathrm{PGF}_{2 \alpha}\right)$ contents in rat ovaries perfused for $10 \mathrm{~h}$. Contents of $\mathrm{PGF}_{2 \alpha}$ in ovaries perfused with $100 \mu \mathrm{mol}$ losartan $\mathrm{I}^{-1}$ alone $(n=5)$ or $100 \mu \mathrm{mol}$ losartan I-1 $+10 \mu \mathrm{mol}$ PD123319 $\mathrm{I}^{-1}(n=6)$ were not significantly different from those of controls $(n=5)$. Bars indicate $10-90 \%$ range; boxes indicate $25-75 \%$ range and horizontal bars indicate medians. IBMX: 3-isobutyl-1-methylxanthine.

minimize the systemic effects of these compounds. Intrabursal administration of $100 \mathrm{ng}$ angiotensin II in $5 \mu \mathrm{l}$ $0.9 \% \mathrm{NaCl}$ reduced ovarian blood flow by $30.4 \%$, with no significant increase in systemic blood pressure (Fig. 6 and Table 1). The amount of ovarian blood flow returned to the pretreatment value within $5 \mathrm{~min}$. After a $10-$ $15 \mathrm{~min}$ interval from the initial injection, the same dose of angiotensin II was given. The effect of this second injection was significantly smaller than that of the initial injection (Fig. 6). Intrabursal injection of $0.9 \%$
$\mathrm{NaCl}$ did not alter blood pressure or ovarian blood flow.

Either of the two angiotensin II antagonists, losartan or PD123319, was administered before angiotensin II. Losartan by itself did not alter ovarian blood flow, but pretreatment with losartan completely blocked angiotensin II-induced ovarian blood flow reduction. In contrast to the effect of losartan, intrabursal injection of PD123319 produced a 52.7\% increase in ovarian blood flow above the baseline value, and the subsequent 


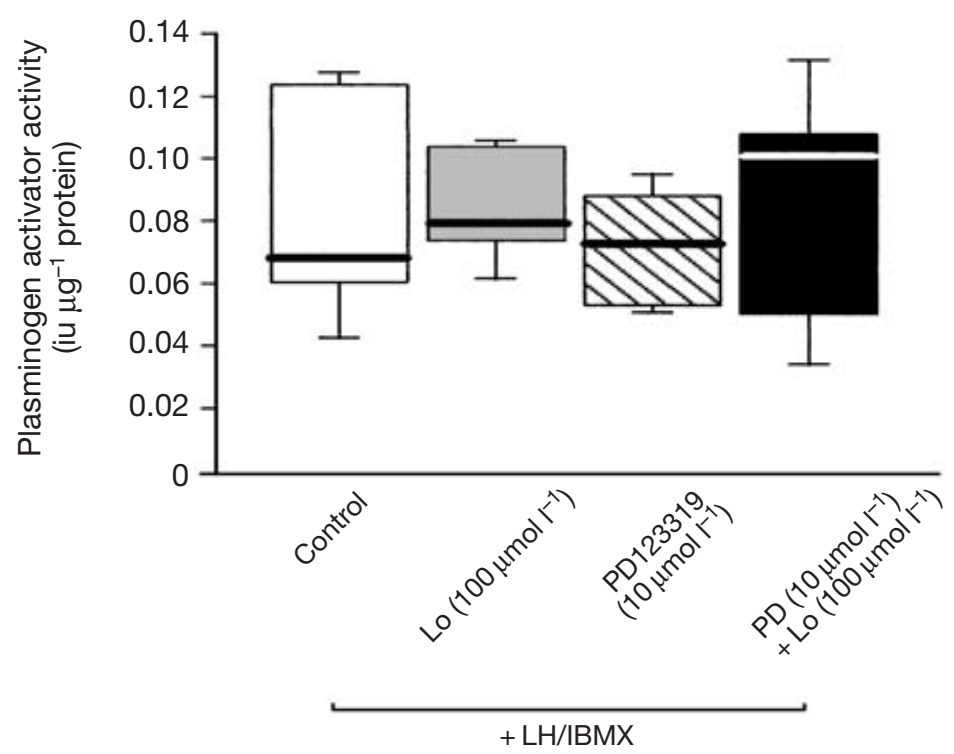

Fig. 5. Plasminogen activator contents in rat ovaries perfused for $10 \mathrm{~h}$. Ovarian plasminogen activator activities in ovaries perfused with $100 \mu \mathrm{mol}$ losartan (Lo) $\mathrm{I}^{-1}$ alone $(n=5)$ or $100 \mu \mathrm{mol}$ losartan $\mathrm{I}^{-1}+$ $10 \mu \mathrm{mol}$ PD123319 $\mathrm{I}^{-1}(n=6)$ were not significantly different from those of controls $(n=5)$. Bars indicate $10-90 \%$ range; boxes indicate 25$75 \%$ range and horizontal bars indicate medians. IBMX: 3-isobutyl-1methylxanthine.

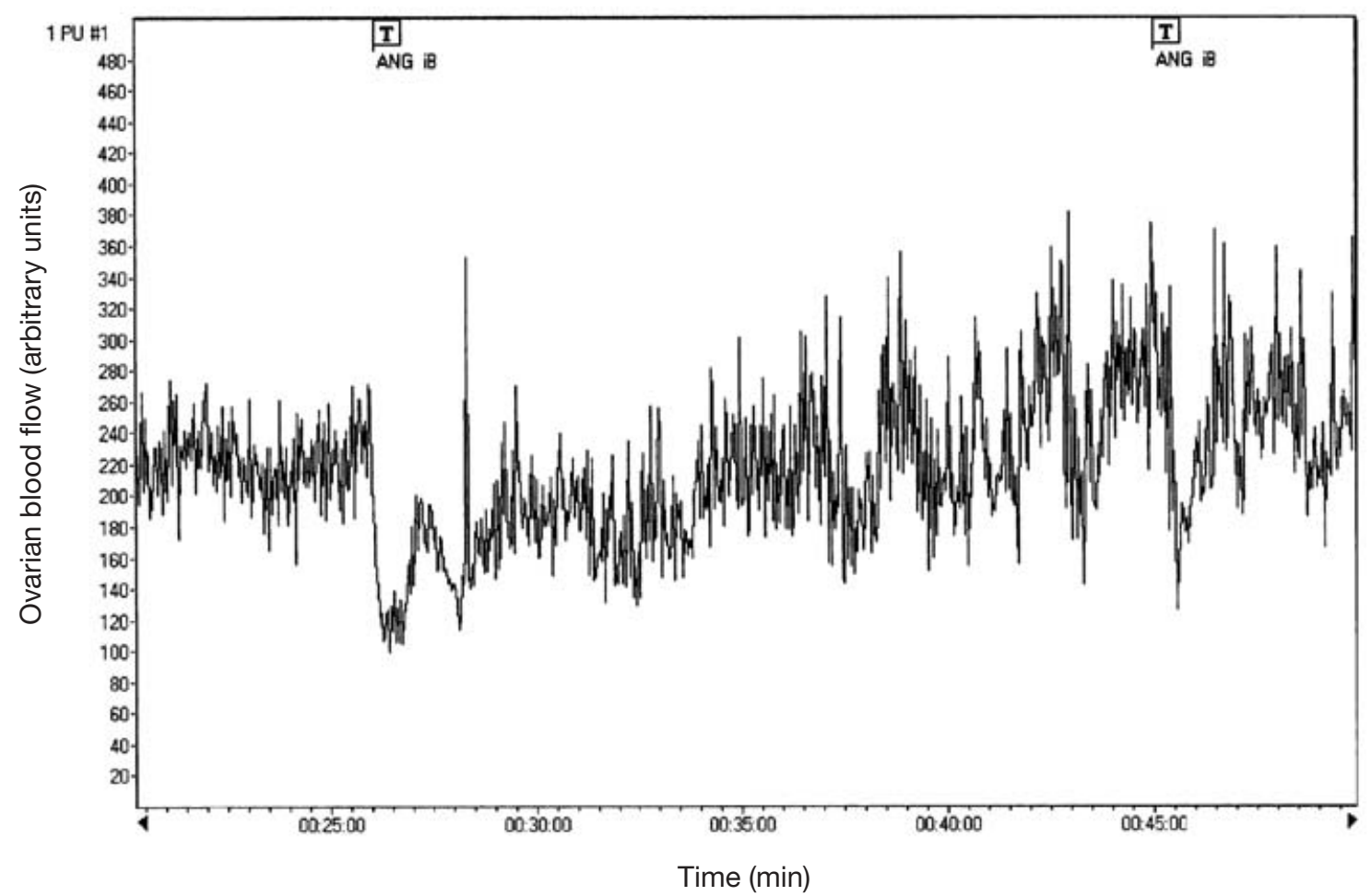

Fig. 6. A representative result of ovarian blood flow measurement by laser Doppler flowmetry. The rats were pretreated sequentially with equine chorionic gonadotrophin and hCG (ovulatory-stage rats). The marks at the top of the figure indicate the sequential injections of angiotensin II (100 ng, intrabursally). The ovarian blood flow values are presented in an arbitrary perfusion units (PU). 
Table 1. Changes of ovarian blood flow and mean systemic arterial pressure in response to intrabursal injection of angiotensin II or angiotensin II-antagonists (first injection) followed by angiotensin II (second injection) in rats pretreated with equine chorionic gonadotrophin $46-48 \mathrm{~h}$ before the experiment (preovulatory stage rats)

\begin{tabular}{|c|c|c|c|c|c|c|}
\hline \multirow{2}{*}{$\begin{array}{l}\text { Treatment } \\
\text { (first injection) }\end{array}$} & \multirow[b]{2}{*}{$n$} & \multicolumn{2}{|c|}{$\begin{array}{c}\text { Ovarian blood flow } \\
\text { (percentage of basal flow) }\end{array}$} & \multicolumn{3}{|c|}{$\begin{array}{c}\text { Mean arterial pressure } \\
(\mathrm{mmHg})\end{array}$} \\
\hline & & First injection & Second injection & Before & First injection & Second injection \\
\hline Control $(0.9 \% \mathrm{NaCl})$ & 6 & $100.2 \pm 0.8$ & $68.5 \pm 5.0^{\dagger \dagger}$ & $76.7 \pm 1.7$ & $76.7 \pm 1.7$ & $86.7 \pm 6.1$ \\
\hline Angiotensin II (100 ng) & 7 & $69.6 \pm 4.1^{* * \dagger \dagger}$ & $85.1 \pm 4.7^{* \dagger}$ & $79.1 \pm 1.5$ & $85.7 \pm 5.3$ & $87.9 \pm 5.0$ \\
\hline Losartan $(40 \mu \mathrm{g})$ & 6 & $115.7 \pm 8.5$ & $113.7 \pm 8.6^{* *}$ & $76.7 \pm 1.7$ & $78.3 \pm 1.7$ & $80.0 \pm 1.3$ \\
\hline PD123319 (40 $\mu \mathrm{g})$ & 6 & $152.7 \pm 11.7^{* * \dagger}$ & $96.7 \pm 10.6^{*}$ & $83.3 \pm 2.1$ & $82.5 \pm 2.1$ & $87.5 \pm 4.8$ \\
\hline
\end{tabular}

Values relative to the pretreatment basal values $(-5$ to $0 \mathrm{~min}$ ) are mean $\pm \mathrm{SEM} ; n=$ number of animals.

${ }^{*} P<0.05$ and ${ }^{* *} P<0.01$; value significantly different from control at each time point.

${ }^{\dagger} P<0.05$ and ${ }^{\dagger \dagger} P<0.01$; value significantly different from the corresponding basal level of the same animal.

Table 2. Changes of ovarian blood flow and mean systemic arterial pressure in response to intrabursal injection of angiotensin II or angiotensin II-antagonists (first injection) followed by angiotensin II (second injection) in rats pretreated sequentially with equine chorionic gonadotrophin and hCG (ovulatory-stage rats)

\begin{tabular}{|c|c|c|c|c|c|c|}
\hline \multirow{2}{*}{$\begin{array}{l}\text { Treatment } \\
\text { (first injection) }\end{array}$} & \multirow[b]{2}{*}{$n$} & \multicolumn{2}{|c|}{$\begin{array}{c}\text { Ovarian blood flow } \\
\text { (percentage of basal flow) }\end{array}$} & \multicolumn{3}{|c|}{$\begin{array}{l}\text { Mean arterial pressure } \\
\qquad(\mathrm{mmHg})\end{array}$} \\
\hline & & First injection & Second injection & Before & First injection & Second injection \\
\hline Control $(0.9 \% \mathrm{NaCl})$ & 5 & $100.2 \pm 1.0$ & $63.0 \pm 2.5^{\dagger \dagger}$ & $83.0 \pm 4.6$ & $86.0 \pm 4.6$ & $87.0 \pm 4.4$ \\
\hline Angiotensin II (100 ng) & 5 & $63.0 \pm 2.5^{* * \dagger \dagger}$ & $91.0 \pm 7.8^{*}$ & $83.0 \pm 4.6$ & $83.0 \pm 4.6$ & $90.0 \pm 5.5$ \\
\hline Losartan $(40 \mu \mathrm{g})$ & 5 & $106.8 \pm 2.7$ & $104.6 \pm 1.9^{* *}$ & $83.8 \pm 5.9$ & $83.8 \pm 5.9$ & $91.3 \pm 5.2$ \\
\hline PD123319 (40 $\mu \mathrm{g})$ & 6 & $121.2 \pm 5.8^{* \dagger}$ & $97.7 \pm 5.4^{* *}$ & $86.7 \pm 1.1$ & $85.8 \pm 1.5$ & $93.3 \pm 3.8$ \\
\hline
\end{tabular}

The experiments were conducted $6-8 \mathrm{~h}$ after hCG. Values relative to the pretreatment basal values $(-5$ to $0 \mathrm{~min})$ are mean \pm SEM; $n=$ number of animals.

${ }^{*} P<0.05$ and ${ }^{* *} P<0.01$; value significantly different from control at each time point.

${ }^{\dagger} P<0.05$ and ${ }^{\dagger \dagger} \mathrm{P}<0.01$; value significantly different from the corresponding basal level of the same animal.

injection of angiotensin II resulted in a decline of the blood flow similar to the initial value. No significant change in frequency in short-term variations of microvascular flow was observed by the treatment with angiotensin II or angiotensin II antagonists. Arterial blood pressure was not significantly altered by any of these intrabursal treatments.

Ovulatory stage rats. The results of the ovarian blood flow measurement in rats treated sequentially with eCG and hCG are presented (Table 2). After the first injection of angiotensin II, ovarian blood flow declined to $63.0 \%$ of the pretreatment value. A second administration of angiotensin II exhibited a lower response than that at the first administration. Losartan did not affect the basal ovarian blood flow and abolished the effect of the following angiotensin II injection. Ovarian blood flow increased by $21.2 \%$ after the injection of PD123319 but returned to the initial value after the following angiotensin II treatment. Neither the systemic blood pressure nor the frequency in variation of microvascular flow was altered by the intrabursal treatment with angiotensin II or angiotensin II antagonists.

\section{Discussion}

The present study was designed to investigate the contribution of $\mathrm{AT}_{1}$ to the ovulatory process by using an $\mathrm{AT}_{1}$ selective antagonist, as our previous study showed that selective inhibition of $\mathrm{AT}_{2}$ by PD123319 did not decrease the number of ovulations in the in vitro perfused rat ovaries (Mikuni et al., 1998). The addition of losartan, a nonpeptide antagonist of angiotensin II with a specific affinity toward $\mathrm{AT}_{1}$, did not influence the number of ovulations in the $\mathrm{LH}$-stimulated perfused rat ovary, whereas the simultaneous blockade of $\mathrm{AT}_{1}$ and $\mathrm{AT}_{2}$ receptors by the combination of losartan and PD123319 reduced ovulation rate almost to the same extent as with saralasin treatment in an identical in vitro model (Peterson et al., 1993; Mikuni et al., 1998). These results imply that in the ovulatory process of the rat, the $\mathrm{AT}_{1}$ and $\mathrm{AT}_{2}$-mediated pathways function in a cooperative or compensatory way and that the inhibition of either pathway is not sufficient to affect ovulation.

The findings of the present study in the rat differ from those in the isolated rabbit ovarian perfusion model, in which both saralasin and PD123319 inhibited ovulation 
whereas the $\mathrm{AT}_{1}$-specific antagonist was without effect (Kuji et al., 1996; Yoshimura et al., 1996). These results indicate that the action of angiotensin II in the rabbit ovulatory process is mediated solely by the $\mathrm{AT}_{2}$ receptor. The discrepancy between the previous results and the results in the present study may be related to inter-species differences, especially in the ovarian localization of angiotensin II receptor subtypes. In the rabbit ovary, $\mathrm{AT}_{2}$ is expressed mainly in the granulosa cells of preovulatory follicles and $\mathrm{AT}_{1}$ is localized to theca cells and ovarian stroma (Yoshimura et al., 1996). In contrast, in the rat ovary, $\mathrm{AT}_{2}$ is detected exclusively in granulosa cells of large antral follicles with the signs of atresia, whereas follicles of healthy appearance do not express $\mathrm{AT}_{2}$ receptor. Angiotensin II receptors expressed in all other structures of the rat ovary examined are of the $\mathrm{AT}_{1}$ type (Pucell et al., 1991; Obermüller et al., 1998). The absence of $\mathrm{AT}_{2}$ expression in any viable part of the ovary, including the preovulatory and ovulatory follicles, and the predominant distribution of $\mathrm{AT}_{1}$ receptor may indicate a relative importance of the $\mathrm{AT}_{1}$ - $^{-}$ mediated pathways in the ovulatory process of the rat.

Intra-ovarian contents of $\mathrm{PGE}_{2}, \mathrm{PGF}_{2 \alpha}$ and PA activity $10 \mathrm{~h}$ after LH stimulation were not affected by either of the angiotensin II antagonists administered alone or in combination. Prostaglandins are recognized as important mediators in the ovulatory process (Richards et al., 1998) and it has been reported that in the gonadotrophinstimulated ovary, the treatment with angiotensin II antagonists resulted in reduced prostaglandin production and also decreased ovulation rate in rabbits (Kuji et al., 1996) and in rats (Mikuni et al., 1998). In the latter studies, prostaglandin concentrations were measured in the media of perfused ovaries, whereas the present study examined the tissue concentrations of these ovulationassociated mediators. Thus, the cause for the discrepancy may be attributable to the difference in the components for the prostaglandin analysis. The ovarian tissue contents at $10 \mathrm{~h}$, which is $2-5 \mathrm{~h}$ before anticipated ovulation, would presumably be a more exact indicator of the biological significance of changed synthesis of any ovarian mediators. It has been suggested that angiotensin II upregulates tissue-type PA and PA inhibitor type I, both of which are thought to be involved in the ovulatory cascade through the control of proteolysis and extracellular matrix breakdown (van Leeuwen et al., 1994). The results of the present study indicate that the blockade of $\mathrm{AT}_{1}$ and $\mathrm{AT}_{2}$ receptors inhibits ovulation without altering ovarian PA activity.

In the present study, continuous measurements of ovarian blood flow with laser Doppler flowmetry revealed that intrabursal administration of angiotensin II rapidly reduced ovarian blood flow. No significant difference in the reduction was observed between preovulatory stage ovary $(30.1 \%$ of the pretreatment value) and ovulatory stage ovary $(37.0 \%)$. This instant reduction in ovarian blood flow is in line with reports on the effects of angiotensin II on local blood flow in other organs, such as the kidney (Chin et al., 1998) and brain (Kramar et al., 1997). The nadir of the flow lasted for 1-2 min and ovarian blood flow returned to the pretreatment values within $5 \mathrm{~min}$ in all observations, as a result of presumably the relatively short half-life (16 s) of angiotensin II in rats (AI-Merani et al., 1978). However, considering the less pronounced effect of the second injection of angiotensin II compared with the first injection, it is possible that angiotensin II activates some type of local compensatory mechanism to maintain ovarian blood flow. Nitric oxide may be one of the mediators involved in this vaso-relaxing property of angiotensin II. In various organs, such as the kidney, $\mathrm{NO}$ has a blood sparing function in the presence of angiotensin II (Chin et al., 1998; Walker et al., 1999), and NO synthase (NOS) is expressed also in the ovary, especially in the vascular-rich theca cell layer (Zackrisson et al., 1996). The results of the present study with ovarian perfusion showed reduction in the ovarian production of $\mathrm{NO}$ by a selective $\mathrm{AT}_{1}$ antagonist losartan. This finding implies that $\mathrm{NO}$ plays a role in maintaining the ovarian blood flow in the presence of angiotensin II. However, the treatment with a combination of losartan and PD123319 completely abolished this reduction in NO production.

In the next set of experiments, the contributions of the $\mathrm{AT}_{1}$ and $\mathrm{AT}_{2}$ receptors in the angiotensin II-mediated reduction of ovarian blood flow were examined. In regulation of systemic blood pressure, the $\mathrm{AT}_{1}$ receptor is known to mediate the pressor effects of angiotensin II, whereas the $\mathrm{AT}_{2}$ receptor has been demonstrated to play antagonistic roles to $\mathrm{AT}_{1}$ (Oliverio et al., 1998; Siragy et al., 1999). Overexpression of the $\mathrm{AT}_{2}$ receptor in aortic vascular smooth muscle cells in transgenic mice completely abolished the $\mathrm{AT}_{1}$-mediated pressor effect of angiotensin II (Tsutsumi et al., 1999). However, there appear to be variations in the angiotensin II receptormediated regulation of local blood perfusion among different organs. Experiments on the uterine artery of rats indicated the mediation of contractile activity of vascular smooth muscle through $\mathrm{AT}_{1}$ and vasorelaxation through $\mathrm{AT}_{2}$ (Zwart et al., 1998). On the contrary in the kidney, $\mathrm{AT}_{2}$-mediated vasoconstriction and reduced renal blood flow were observed in vivo in mice and in vitro in an isolated perfusion model of the rat (Müller et al., 1998; Ruan et al., 1999).

In the present study, the blockade of $\mathrm{AT}_{1}$ receptor with losartan did not affect the basal ovarian blood flow but intrabursal administration of PD123319 significantly increased the blood flow in the ovary. This result could be interpreted as indicating that in the preovulatory rat ovary, blood vessels are mainly constricted through $\mathrm{AT}_{2}$ and not through $\mathrm{AT}_{1}$. Considering the tissuespecific localization of angiotensin II receptors in the ovary, this finding may indicate that $\mathrm{AT}_{2}$, which is 
exclusively expressed in the atretic follicles of the rat (Obermüller et al., 1998), selectively constricts blood vessels in this region and reduces blood supply to the atretic follicles. However, pretreatment with losartan completely eliminated the action of angiotensin II to reduce the ovarian blood flow but PD123319 was without effect, indicating that the effect of exogenously added angiotensin II was exerted mainly through the $\mathrm{AT}_{1}$ receptor.

These findings may be explained by two models. The first model is based on a compartmentalization of local concentrations of angiotensin II within the ovary. As the $\mathrm{AT}_{2}$ receptor is localized exclusively to the atretic follicles of the rat, if the concentration of angiotensin II in this compartment is higher than in the other parts of the ovary, blood flow in this region may be selectively restricted. If $\mathrm{AT}_{2}$ activation is almost saturating, any additional angiotensin II will have no further effect. It is of note that higher concentrations of prorenin and $\mathrm{ACE}$ are detected in the $\mathrm{AT}_{2}$-expressing atretic follicles (Speth and Husain, 1988; Schultze et al., 1989). The second model is that there are compensatory mechanisms against $\mathrm{AT}_{1}$-mediated vasoconstriction in the ovary. These mechanisms may be able to maintain the ovarian blood flow under physiological conditions but cannot counteract the action of the excessive amount of angiotensin II that was administered in the experiment. Nitric oxide may be involved in this compensatory mechanism since NOS coexists with $\mathrm{AT}_{1}$ in the theca cell layer and ovarian stroma, and the results of the present perfusion study in vitro indicate that angiotensin II stimulates ovarian production of $\mathrm{NO}$ through $\mathrm{AT}_{1}$. These models may be in line with the previous observations that vasoconstriction in parts of the ovary redirects blood flow from atretic follicles to healthy preovulatory follicles (Scanes et al., 1982). This redistribution and increase of blood flow in and around the ovulatory follicles is considered to be essential for the ovulatory process to proceed until follicular rupture (Janson, 1975).

In summary, the present findings demonstrate that simultaneous blockade of $\mathrm{AT}_{1}$ and $\mathrm{AT}_{2}$ receptors inhibits gonadotrophin-induced ovulation in the rat, whereas only the $\mathrm{AT}_{1}$ selective antagonism is without effect. The mechanisms underlying this inhibition of ovulation is not likely through the modulation of PG synthesis or PA activity. Ovarian blood flow during the preovulatory period is negatively regulated by angiotensin II and under physiological conditions, $\mathrm{AT}_{2}$ receptor seems to be the receptor subtype involved. Exogenously administered angiotensin II exerts the vasoconstrictive effect through $\mathrm{AT}_{1}$ receptor, and the presence of compensatory mechanisms to maintain ovarian blood flow is indicated.

This study was supported by grants from the Swedish Medical Research Council (11607 to M. Brännström), Hjalmar Svensson Research Foundation and Medical Faculty of Göteborg University.

\section{References}

Abisogun AO, Daphna-Iken D, Reich R, Kranzfelder D and Tsafriri A (1988) Modulatory role of eicosanoids in vascular changes during the preovulatory period in the rat Biology of Reproduction 38 756-762

Al-Merani SA, Brooks DP, Chapman BJ and Munday KA (1978) The halflives of angiotensin II, angiotensin II-amide, angiotensin III, Sar1-Ala8angiotensin II and renin in the circulatory system of the rat Journal of Physiology (London) 278 471-490

Brännström M, Johansson BM, Sogn J and Janson PO (1987) Characterization of an in vitro perfused rat ovary model: ovulation rate, oocyte maturation, steroidogenesis and influence of PMSG priming Acta Physiologica Scandinavica 130 107-114

Chin SY, Wang CT, Majid DS and Navar LG (1998) Renoprotective effects of nitric oxide in angiotensin II-induced hypertension in the rat American Journal of Physiology 274 F876-878

Espey L, Shimada H, Okamura H and Mori T (1985) Effect of various agents on ovarian plasminogen activator activity during ovulation in pregnant mare's serum gonadotropin-primed immature rats Biology of Reproduction 32 1087-1094

Fernandez LA, Tarlatzis BC, Rzasa PJ, Caride VJ, Laufer N, Negro-Vilar AF, DeCherney AH and Naftolin F (1985) Renin-like activity in ovarian follicular fluid Fertility and Sterility 44 219-223

Howard RB, Pucell AG, Bumpus FM and Husain A (1988) Rat ovarian renin: characterization and changes during the estrous cycle Endocrinology $1232331-2340$

Janson PO (1975) Effects of the luteinizing hormone on blood flow in the follicular rabbit ovary, as measured by radioactive microspheres Acta Endocrinologica 79 122-133

Kramar EA, Harding JW and Wright JW (1997) Angiotensin II- and IVinduced changes in cerebral blood flow. Roles of $\mathrm{AT}_{1}, \mathrm{AT}_{2}$, and $\mathrm{AT}_{4}$ receptor subtypes Regulatory Peptides 68 131-138

Kranzfelder D, Reich R, Abisogun AO and Tsafriri A (1992) Preovulatory changes in the perifollicular capillary network in the rat: role of eicosanoids Biology of Reproduction 46 379-385

Kuji N, Sueoka K, Miyazaki T, Tanaka M, Oda T, Kobayashi T and Yoshimura Y (1996) Involvement of angiotensin II in the process of gonadotropininduced ovulation in rabbits Biology of Reproduction 55 984-991

Lightman A, Tarlatzis BC, Rzasa PJ, Culler MD, Caride VJ, Negro-Vilar AF, Lennard D, DeCherney AH and Naftolin F (1987) The ovarian reninangiotensin system: renin-like activity and angiotensin II/III immunoreactivity in gonadotropin-stimulated and unstimulated human follicular fluid American Journal of Obstetrics and Gynecology 156 808-816

Lissbrant E, Lofmark U, Collin O and Bergh A (1997) Is nitric oxide involved in the regulation of the rat testicular vasculature? Biology of Reproduction 56 1221-1227

Makinoda S, Tabata M, Yamaguchi T, Nakajin K, Koyama T and Ichinoe K (1988) Ovarian blood flow and oxygen transport to the follicle during the preovulatory period Advances in Experimental Medicine and Biology 222 689-697

Mikuni M, Brännström M, Hellberg P, Peterson CA, Pall M, Edwin SS and Peterson CM (1998) Saralasin-induced inhibition of ovulation in the in vitro perfused rat ovary is not replicated by the angiotensin II type2 receptor antagonist PD123319 American Journal of Obstetrics and Gynecology 179 35-40

Müller C, Endlich K and Helwig JJ (1998) Role of eicosanoids in renal angiotensin II vasoconstriction during nitric oxide blockade Kidney International Supplement 67 S234-237

Murakami T, Ikebuchi Y, Ohtsuka A, Kikuta A, Taguchi T and Ohtani O (1988) The blood vascular wreath of rat ovarian follicle, with special reference to its changes in ovulation and luteinization: a scanning electron microscopic study of corrosion casts Archives of Histology and Cytology 51 299-313

Obermüller N, Schlamp D, Hoffmann S, Gentili M, Inagami T, Gretz N and Weigel $\mathbf{M}$ (1998) Localization of the mRNA for the angiotensin II receptor subtype $2\left(\mathrm{AT}_{2}\right)$ in follicular granulosa cells of the rat ovary by nonradioactive in situ hybridization Journal of Histochemistry and Cytochemistry: Official Journal of the Histochemistry Society $\mathbf{4 6}$ 865-870 
Oliverio MI, Kim HS, Ito M et al. (1998) Reduced growth, abnormal kidney structure, and type $2\left(\mathrm{AT}_{2}\right)$ angiotensin receptor-mediated blood pressure regulation in mice lacking both $\mathrm{AT}_{1 \mathrm{~A}}$ and $\mathrm{AT}_{1 \mathrm{~B}}$ receptors for angiotensin II Proceedings National Academy of Sciences USA 9515 496-15 501

Pellicer A, Palumbo A, DeCherney AH and Naftolin F (1988) Blockage of ovulation by an angiotensin antagonist Science 240 1660-1661

Peterson CM, Zhu C, Mukaida T, Butler TA, Woessner JF, Jr and LeMaire WJ (1993) The angiotensin II antagonist saralasin inhibits ovulation in the perfused rat ovary American Journal of Obstetrics and Gynecology 168 242-245

Pucell AG, Hodges JC, Sen I, Bumpus FM and Husain A (1991) Biochemical properties of the ovarian granulosa cell type 2-angiotensin II receptor Endocrinology 128 1947-1959

Richards JS, Russell DL, Robker RL, Dajee M and Alliston TN (1998) Molecular mechanisms of ovulation and luteinization Molecular and Cellular Endocrinology 145 47-54 Review

Ruan X, Oliverio MI, Coffman TM and Arendshorst WJ (1999) Renal vascular reactivity in mice: Ang Il-induced vasoconstriction in $\mathrm{AT}_{1 \mathrm{~A}}$ receptor null mice Journal of the American Society of Nephrology 10 $2620-2630$

Scanes CG, Mozelic H, Kavanagh E, Merrill G and Rabii J (1982) Distribution of blood flow in the ovary of domestic fowl (Gallus domesticus) and changes after prostaglandin $\mathrm{F}_{2 \alpha}$ treatment Journal of Reproduction and Fertility 64 227-231

Schultze D, Brunswig B and Mukhopadhyay AK (1989) Renin and proreninlike activities in bovine ovarian follicles Endocrinology 124 13891398

Sealey JE, Atlas SA, Glorioso N, Manapat H and Laragh JH (1985) Cyclical secretion of prorenin during the menstrual cycle: synchronization with luteinizing hormone and progesterone Proceedings National Academy of Sciences USA 82 8705-8709

Siragy HM, Senbonmatsu T, Ichiki T, Inagami T and Carey RM (1999) Increased renal vasodilator prostanoids prevent hypertension in mice lacking the angiotensin subtype-2 receptor Journal of Clinical Investigation 104 181-188

Speth RC and Husain A (1988) Distribution of angiotensin-converting enzyme and angiotensin II-receptor binding sites in the rat ovary Biology of Reproduction 38 695-702

Tsutsumi Y, Matsubara H, Masaki H et al. (1999) Angiotensin II type 2 receptor overexpression activates the vascular kinin system and causes vasodilation Journal of Clinical Investigation 104 925-935

van Leeuwen RT, Kol A, Andreotti F, Kluft C, Maseri A and Sperti G (1994) Angiotensin II increases plasminogen activator inhibitor type 1 and tissue-type plasminogen activator messenger RNA in cultured rat aortic smooth muscle cells Circulation 90 362-368

Walker LL, Rajaratne AA, Blair-West JR and Harris PJ (1999) The effects of angiotensin II on blood perfusion in the rat renal papilla Journal of Physiology 519 273-278

Wiltbank MC, Gallagher KP, Christensen AK, Brabec RK and Keyes PL (1990) Physiological and immunocytochemical evidence for a new concept of blood flow regulation in the corpus luteum Biology of Reproduction 42 139-149

Yoshimura Y, Koyama N, Karube M, Oda T, Akiba M, Yoshinaga A, Shiokawa S, Jinno M and Nakamura Y (1994) Gonadotropin stimulates ovarian renin-angiotensin system in the rabbit Journal of Clinical Investigation 93 180-187

Yoshimura Y, Karube M, Aoki H, Oda T, Koyama N, Nagai A, Akimoto Y, Hirano H and Nakamura $\mathbf{Y}$ (1996) Angiotensin II induces ovulation and oocyte maturation in rabbit ovaries via the $\mathrm{AT}_{2}$ receptor subtype Endocrinology 137 1204-1211

Zackrisson U, Mikuni M, Wallin A, Delbro D, Hedin L and Brännström M (1996) Cell-specific localization of nitric oxide synthases (NOS) in the rat ovary during follicular development, ovulation and luteal formation Human Reproduction 11 2667-2673

Zackrisson U, Mikuni M, Peterson MC, Nilsson B, Janson PO and Brännström M (2000) Evidence for the involvement of blood flow-related mechanisms in the ovulatory process of the rat Human Reproduction $\mathbf{1 5}$ 264-272

Zwart AS, Davis EA and Widdop RE (1998) Modulation of $\mathrm{AT}_{1}$ receptormediated contraction of rat uterine artery by $\mathrm{AT}_{2}$ receptors British Journal of Pharmacology 125 1429-1436

Received 22 August 2002.

First decision 11 October 2002.

Revised manuscript received 21 November 2002.

Accepted 29 November 2002. 